THE KURUME MEDICAL JOURNAL

1974 Vol.21, No.4, P.111-115

\title{
FRACTIONATION OF URINARY GLYCOPEPTIDE BY DEAE SEPHADEX A-50 COLUMN CHROMATOGRAPHY
}

\author{
HIROSHI MASUDA, SHIGEKI SHICHIJO \\ AND MUTSUYA TAKEUCHI \\ Institute of Clinical Pathology, Kurume University School of Medicine, \\ Kurume, Japan
}

(Received for publication November 24, 1974)

\begin{abstract}
Glycopeptides in normal human urine were assayed by determining the carbohydrate content of material which remained after proteolysis.

Fractionation of nondialyzable glycopeptide by DEAE Sephadex A-50 column chromatography yielded five fraction which were characterized by an increase in peptide and sialic acid as the molarity of Tris-HCl buffer increased. The sugar components consisted of galactose, mannose, fucose, sialic acid, glucosamine and galactosamine.
\end{abstract}

Various urinary carbohydrate compounds, especially Tamm-Horsfall glycoprotein ${ }^{13) 9)}$ have been studied. Recently, Bron $^{1)}$ has reported an urinary glycoprotein antigenically related to human red cell membrane. Nine years ago, Miettinon ${ }^{8)}$ isolated three glycopeptides from patients and pointed out that they might be concerned to the syndrome of complicated antibody deficiency as well as to psychiatric stress. On the other hand, Shetlar ${ }^{12)}$ found uronic acid containing polypeptides in the urine of burned patients and Masuda ${ }^{7)}$ isolated sialic acid rich glycopeptide from the urine of myoclonus epilepsy (Laforabody type). In view of the increasing importance of urinary glycopeptides in diagnosis, the present study was carried out for the purpose of isolating and characterizing glycopeptides from the urine of healthy adults.

\section{MATERIALS AND METHODS}

Materials.

Complete $24 \mathrm{hr}$ urine samples, preser- ved with $0.1 \%$ sodium azide, werecollected from 10 healthy, active Japanese, not in hospital with ages ranging from 25-40 years. At the end of collection period, volumes of the samples were measured and the urines were stored in the deep freezer untill further work was undertaken.

\section{Isolation of crude glycopeptides} from the urine.

Crude glycopeptides were isolated from the urine according to the procedure shown in Fig. 1. The urines were brought to room temperature and digested with papain [EC $3,4,4,10]$ in the presence of EDTA and cysteine at $65{ }^{\circ} \mathrm{C}$ for $48 \mathrm{hr}$. The mixture was adjusted to $\mathrm{pH} 7.8$ and then digested with trypsin $[\mathrm{EC} 3,4,4,4]$ at $37^{\circ} \mathrm{C}$ for $48 \mathrm{hr}$ with simultaneous dialysis against $0.1 \mathrm{M}$ phosphate buffer of $\mathrm{pH}$ 7.8. The digested solution was deproteinized with $5 \%$ trichloroacetic acid in the cold and the supernatant was dialyzed against several changes of the cold deionized water for $72 \mathrm{hr}$. Then 4 volumes of alcohol containing $1 \%$ acetic acid and $1 \%$ 
Urine, dialysis<smiles>[TlH]</smiles>

Digest with papain two overnights at $65^{\circ} \mathrm{C}$

in the presence of EDTA and cysteine. I

Digest with trypsin two overnights at $37^{\circ} \mathrm{C}$. |

Precipitate the residual protein with cold $5 \%$ TCA.

Dialyze three overnights in the cold.

I

Precipitate the glycopeptide and the AMPS mixture with adding 4 volumes of $95 \%$ al cohol (containing $1 \%$ acetic acid and $1 \%$ $\mathrm{K}$-acetate).

I

Wash it with $80 \%$ alcohol and air-dry.

।

Dissolve the precipitate with distilled water. (Glycopeptide and AMPS mixture)

Fig. 1 Extraction of urinary glycopeptide.

potassium acetate were added to precipitate the crude glycopeptide. The precipitate was washed with alcohol, dried in a $\mathrm{CaCl}_{2}$ desiccator and then redissolved in $5 \mathrm{ml}$ of deionized water. An aliquot (usually $0.5 \mathrm{ml}$ respectively) was used for hexose, sialic acid and uronic acid analyses.

\section{Electrophoresis of glycopeptides on} a cellulose acetate strip.

Material was run in a horizontal type apparatus at constant current of 0.4 $\mathrm{mA} / \mathrm{cm}$ for $40 \mathrm{~min}$. on an OXOID strip $(8 \times 1.2 \mathrm{~cm})$ in barbital buffer, $\mathrm{pH} 8.6$, $\mu=0.06$. After electrophoresis, the strip was stained with alcian blue and PAS in the normal way using human serum, hyaluronic acid and chondroitin sulfate as standards.

Fractionation of glycopeptides by $D E A E$ Sephadex A-50 column chroma tography.

DEAE Sephadex A-50 (a product of pharmacia, Uppsala, Sweden) was equilibrated with $0.1 \mathrm{M}$ Tris- $\mathrm{HCl}$ buffer, $\mathrm{pH}$ 8.0, which was used as the starting buffer for a gradient elution system. 20 $\mathrm{ml}$ of $2.5 \%$ dry material in the starting buffer was applied to a DEAE Sephadex A-50 column $(2.5 \times 45 \mathrm{~cm})$. Elution was made with a linear gradient of $0.1-1.0 \mathrm{M}$ Tris-HCl buffer. The total elution volume was 1 liter. The eluant was collected in $15 \mathrm{ml}$ fractions at a flow rate of $30 \mathrm{ml}$ per $\mathrm{hr}$. An aliquot (usually $0.5 \mathrm{ml}$ respectively) was used for hexose and peptide analyses. Isolated fractions were dialyzed against deionized water and used for electrophoresis on cellulose acetate strip and chemical analyses.

\section{Analytical procedures.}

Protein content was determined by the Lowry method ${ }^{5)}$, human serum (Hyland Laboratory, U.S. A.) being used as a standard. Hexose content wasdetermined by the tryptophane method of Shetlar, Foster and Everett ${ }^{10}$, a mixture of manñose and galactose being used as a standard. Sialic acid content was determined using the Warren periodic oxidation-thiobarbituric acid method ${ }^{14}$, $\mathrm{N}$ acetylneuraminic acid being used as a standard. Neutral sugars were separated and identified by paper chromatography, after hydrolysis with $1 \mathrm{~N} \mathrm{HCl}$ for $3 \mathrm{hr}$ at $100^{\circ} \mathrm{C}$ in a sealed ampoule.

S \& S filter paper No. 598 was used as a supporting medium; the solvent system was n-butanol-pyridine-0.1 N HCl $(5: 3: 2 \mathrm{v} / \mathrm{v} / \mathrm{v})$. Descending paper chromatography and double development techniques were used ; chromatogram was stained with $\mathrm{AgNO}_{3}-\mathrm{NaOH}$ reagent.

The separation and quantitative determination of glucosamine and galactosamine were carried out with a $\mathrm{Hi}$ tachi KLA-3 Amino Acid Analyser, using a $50 \mathrm{~cm}$ column in citrate buffer of $\mathrm{pH} 5.28(\mathrm{Na}: 0.35 \mathrm{~N})$ after hydrolysis with $4 \mathrm{~N} \mathrm{HCl}$ for $6 \mathrm{hr}$ at $100^{\circ} \mathrm{C}$ in the sealed ampoule. 


\section{RESULTS AND DISCUSSION}

Results of the hexose and sialic acid analyses of the glycopeptide with simultaneous analysis of the uronic acid of the acid mucopolysaccharide of urines for 10 normal are summarized in Table 1 . Cornelius et al. ${ }^{2}$ reported that TammHorsfall glycoprotein content was $25 \mathrm{mg}$. per liter.

On the uronic acid values, DiFerrante et al. ${ }^{3)}$ reported $4.4^{-7} .3 \mathrm{mg} /$ day for man and $2.5-5.4 \mathrm{mg} / \mathrm{day}$ for woman, respectively. Iwashita et al. ${ }^{4)}$ reported $1.5-4.0$ $\mathrm{mg}$ /day without regards to the sex and Shetlar et al. ${ }^{2}$ ) reported $7-12 \mathrm{mg}$ for male American and 6-7 $\mathrm{mg}$ for female American, respectively. Our values are similar to these data.
TABLE 1

Excretion of glycopeptide and acid mucopolysaccharide in normal human urine $(m g / 24 h r s)$

\begin{tabular}{l|c|c|c} 
Subject & Sialic acid & Hexose & $\begin{array}{c}\text { Uronic } \\
\text { acid }\end{array}$ \\
1. Male & 5.1 & 14.1 & 4.7 \\
2. Male & 4.5 & 27.0 & 5.8 \\
3. Male & 4.4 & 21.3 & 5.3 \\
4. Male & 4.1 & 17.6 & 5.0 \\
5. Male & 3.8 & 20.2 & 5.7 \\
6. Male & 3.5 & 24.2 & 7.4 \\
7. Male & 2.4 & 19.2 & 5.7 \\
8. Male & 4.7 & 10.1 & 4.4 \\
9. Male & 3.3 & 23.3 & 9.2 \\
10. Female & 4.0 & 10.8 & 5.1 \\
& $4.0 \pm 0.8$ & $18.8 \pm 5.7$ & $5.8 \pm 1.4$ \\
\hline
\end{tabular}

Alcian blue stain

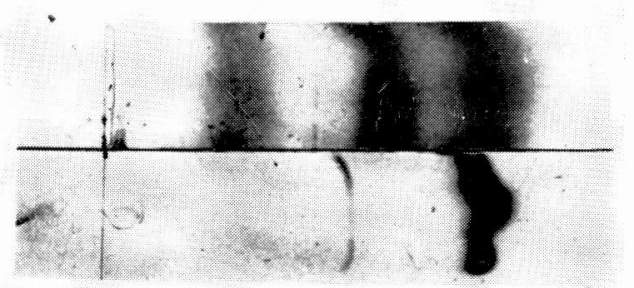

PAS stain

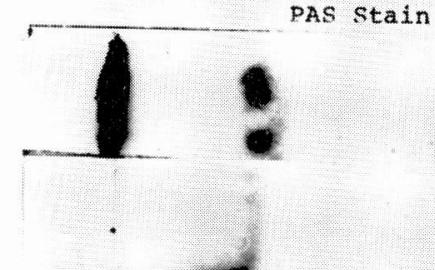

Ponceau-s Stain

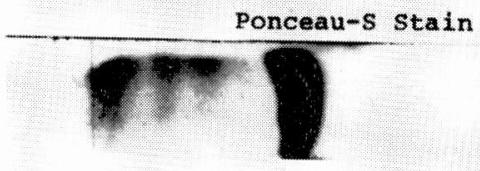

Fig. 2 Cellulose acetate strip-electrophoresis of the crude glycopeptide from the urine of normal human. 
Electrophoretic pattern of the crude material in the barbital buffer, $\mathrm{pH} 8.6$ are shown in Fig. 2. When stained with alcian blue, the material had four components which moved towards the anode. This is in agreement with Manley et al. ${ }^{6)}$ who reported one glycoprotein and three acid mucopolysaccharides from the urine; heparan sulfate, chondroitin sulfate and hyaluronic acid, respectively. When stained with PAS, the material had one component which moved slightly towards the anode. This component corresponds to the component which migrated towards the anode slower than hyaluronic acid and was stained with alcian blue.

The elution pattern of the DEAE Sephadex A-50 column chromatography of the crude material is shown in Fig. 3. The material separated into 5 hexose peaks. Fractions corresponding to these peaks were poold and dialyzed against deionized water for 2 days; insoluble material was centrifuged out and the supernatants were freeze-dried and then subjected to the chemical analyses.

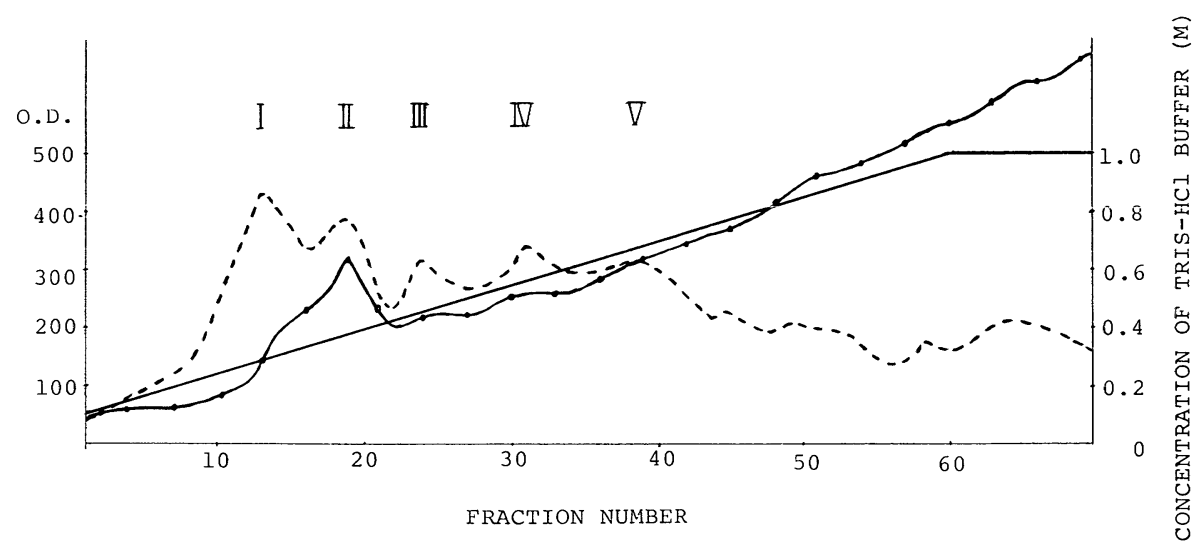

Fig. 3 Chromatogram of a DEAE sephadex A-50 elution.

- Concentration of tris- $\mathrm{HCl}$ buffer (M)

Hexose content

-.-.-. Absorbance at 280 millimicron

TABLE 2

Analyses of fractions from DEAE sephadex A-50 column chromatography (\% weight)

\begin{tabular}{l|c|c|c|c|c}
\hline & Fraction ( I )* & Fraction (II)* & Fraction (II)* Fraction (IV) & Fraction (V) \\
\hline Hexose & 51.8 & 41.8 & 40.9 & 49.5 & 50.0 \\
Peptide & 11.5 & 17.6 & 17.4 & 19.2 & 22.7 \\
Sialic acid & trace & trace & trace & 4.0 & 5.8 \\
Glucosamine & 8.5 & 6.2 & 6.1 & 6.2 & 6.6 \\
Galactosamine & 3.4 & 2.1 & 2.2 & 1.9 & 2.1 \\
\hline
\end{tabular}

* Uronic acid was detected in the fraction I through $\mathrm{III}$, though the carbazole reaction was not so typical of uronic acid as usual, but with a colour of brown. 
These various fractions were subjected to analyses for hexose, sialic acid, hexosamine, peptide and uronic acid content; results are summarized in Table 2. They were characterized by an increase in peptide and sialic acid as the molarity of Tris-HCl buffer increased.

The carbazole reaction gave a brown color which was not typical of uronic acid, and uronic acid was detected in fraction I through III. This may show that unfortunately hyaluronic acid might be contaminated into these fractions. Further purification of the fraction I through III will be necessary and is in progress now.

Paper chromatography revealed the presence of galactose, mannose and fucose in each fraction.

\section{REFERENCES}

1) Bron, C. and Poulik, M.D. : Urinary glycoprotein antigenically related to human red cell membrane. Immunochem., 8, 447, 1971.

2) Cornelius, C. E. : Studies on Ovine Urinary Biocolloids and Phosphatic Calculosis. Ann. N. Y. Acad. Sci., 104, 638, 1963.

3 ) DiFerrante, N. and Rich, C.: The determination of acid aminopolysaccharide in urine., J. Lab. Clin. Med., 48, 491, 1956.

4 ) Iwashita, Y., Baba, H., Nakashima, Y., Fukushima, A., Sato, S. and Masuda, H. : Studies on Urinary Mucopolysaccharides of Man in Normal and Diseased States. J. Kurume Med. Assoc., 28, 625, 1965.
5 ) Lowry,O.H., Rosebrough, N.J., Farr, A.L. and RANDAlL, R.J. : Folin Phenol Reagent for the Determination of Protein. J. Biol. Chem., 193, 25, 1951.

6 ) Manley, G., Seuern, M. and Hawskworth, J.: Excretion patterns of glycosaminoglycans and glycoproteins in normal human urine. J. Clin. Path., 21, 339, 1968.

7 ) Masuda, H., Takeuchi, M., Kunitake, A. and ANRAKU, S. : Isolation and Characterization of Glycopeptide from the Urine of Myoclonus Epilepsy (Lafora). Japanese J Clin. Path., in press.

8 ) Miettinen,T.A. : Fractionation of Urinary Mucopolysaccharides by Gel Filtration. Scandinav. J. Clin. La. Invest., 14, 380, 1962 .

9 ) Odin, L.: Analysis from Tamm-Horsfall Glycoprotein. Nature, 170, 663, 1952.

10) Shetlar, M.R., Foster, J.V. and Everett, M.R. : Determination of Serum Polysaccharides by the Tryptophane Reaction. Proc. Soc. Exptl. Biol. \& Med., 67, 125, 1948.

11) Shetlar, M.R.: Progress in Clinical Pathology, 1, 439, 1966, Grune \& Stratton, New York.

12) Shetlar, M.R., Hern, D. and Shurely, H. : Uronic Acid-Containing Polypeptides from the Urine of Burned Patients. Proc. Soc. Exptl. Biol. Med., 132, 999, 1969.

13) Tamm, I. and Horsfall, F.L.Jr.: Characterizaation and Separation of An Inhibitor of Viral Hemagglutination Prezent in Urine. Proc. Soc. Exptl. Biol. Med., 74, 108, 1950.

14) WARren, L.: The Thiobarbituric Acid of Sialic Acid. J. Biol.Chem., 234, 1971, 1959. 